\title{
BERN RADIOCARBON DATES VI
}

\section{H. OESCHGER and T. RIESEN}

Physikalisches Institut, Universität Bern

This date list consists of some of the samples measured since summer 1965. For the routine measurements the same technique and equipment as described earlier was used (Bern IV).

Besides, with two specially designed counters, samples containing as little as 20 to $50 \mathrm{mg}$ carbon were analyzed (Loosli, 1963; Oeschger, 1963). Up to now this technique has been applied only to $\mathrm{CO}_{2}$ samples extracted from polar ice. These results are listed with numbers above B-1000.

Our laboratory is financed by the Schweizerischer Nationalfonds. The authors wish to thank P. Horisberger and H. H. Loosli for their assistance in the measurement of the samples. They also thank M. Welten and H. G. Bandi for their help in selecting and discussing the samples.

\section{Tuto series, Greenland (Table 1)}

During a joint research project with USA CRREL during MarchApril 1964, $\mathrm{CO}_{2}$ was extracted from ice of Tuto Tunnel $\left(76^{\circ} 28^{\prime} \mathrm{N}\right.$ Lat, $68^{\circ} 13^{\prime}$ W Long), North Greenland, which runs $350 \mathrm{~m}$ horizontally into ice sheet. Samples were collected $200 \mathrm{~m}$ and $300 \mathrm{~m}$ from tunnel portal. Ice was melted in vacuo and two different methods for collecting $\mathrm{CO}_{2}$ were applied: precipitation in $\mathrm{NaOH}(\operatorname{method} 1)$ and trapping in molecular sieve 4 A (method 2) (Langway et al., 1965; Oeschger et al., 1966). For measurement $\mathrm{CH}_{4}$ was prepared (Bern IV). Samples out of ca. one ton of ice yielded 50 to $100 \mathrm{cc}$ of $\mathrm{CO}_{2}$. Most $\mathrm{CO}_{2}$ is assumed to be atmospheric. Ages therefore were calculated based on a modern (prebomb) C-activity for atmospheric $\mathrm{CO}_{2}$ equal to $0.95 \mathrm{NBS}$ oxalic acid x 1.037 . Coll. by C. C. Langway, Jr., USA CRREL and H. Oeschger, Univ. of Bern. Comment (H.O.): from geometrical array of ice layers and from general rheological knowledge age was expected to increase towards tunnel portal, which is agreement with $\mathrm{C}^{14}$ results. Series looks consistent with exception of $\mathrm{B}-1011$, which is at $3 \sigma$ limit. Mean $\mathrm{C}^{14}$-age at $300 \mathrm{~m}$ is $2420 \pm 185$, at $200 \mathrm{~m}$ it is $5350 \pm 260$. Young age of B-1011 might be due to contamination with recent atmospheric $\mathrm{CO}_{2}$. In March-April 1966 this project was repeated and samples were collected from each 100 $\mathrm{ft}$. A new in situ extraction technique was developed and successfully applied. Results from 1966 project are not yet complete and will be published later.

\section{Motta Naluns series, Switzerland}

A profile of $290 \mathrm{~cm}$ of well-preserved turf, consisting of sedges, Hypnaceae and wood of Salix, was taken from wall cut in bog on left- 
TABLF. 1

$\mathrm{C}^{14}$ ages of ice in Tuto tunnel, $\mathbf{N}$ Greenland

\begin{tabular}{lccc}
\hline Sample No. & Distance from portal & Method & $\begin{array}{c}\text { Age, calculated from } \\
\text { modern prebomb } \\
\text { atmospheric CO, activity }\end{array}$ \\
\hline B-1002 & 300 & 2 & $2850 \pm 320$ \\
B-1004 & 300 & 2 & $2760 \pm 300$ \\
B-1011 & 300 & 1 & $1370 \pm 360$ \\
B-1010 & 300 & 2 & $2700 \pm 800$ \\
B-1003 & 200 & 2 & $6030 \pm 700$ \\
B-1005 & 200 & 1 & $5400 \pm 400$ \\
B-1009 & 200 & & $5040 \pm 400$ \\
\hline
\end{tabular}

hand slope above Schuls-Tarasp (46 $48^{\prime} 22^{\prime \prime} \mathrm{N}$ Lat, $10^{\circ} 16^{\prime} 25^{\prime \prime} \mathrm{E}$ Long, alt $2170 \mathrm{~m}$ ). Coll. 1962 and subm. by M. Welten. Comment (M.W.): pollen diagram is accurately dated by this consistent series of results.

B-532. Motta Naluns, $50 \mathrm{~cm}$ depth

B-533. Motta Naluns, $81 \mathrm{~cm}$ depth

B-534. Motta Naluns, $120 \mathrm{~cm}$ depth

B-535. Motta Naluns, $130 \mathrm{~cm}$ depth

B-536. Motta Naluns, $142 \mathrm{~cm}$ depth

B-537. Motta Naluns, $160 \mathrm{~cm}$ depth

B-538. Motta Naluns, $174 \mathrm{~cm}$ depth

B-539. Motta Naluns, $193 \mathrm{~cm}$ depth

B-541. Motta Naluns, $230 \mathrm{~cm}$ depth

B-542. Motta Naluns, $248 \mathrm{~cm}$ depth

B-543. Motta Naluns, $265 \mathrm{~cm}$ depth

B-544. Motta Naluns, $276 \mathrm{~cm}$ depth

$$
\begin{aligned}
& 2020 \pm 100 \\
& 70 \text { B.c. } \\
& 2620 \pm 100 \\
& 670 \text { B.C. } \\
& 3890 \pm 100 \\
& 1940 \text { B.C. } \\
& 3890 \pm 100 \\
& 1940 \text { в.C. } \\
& 4130 \pm 100 \\
& 2180 \text { B.C. } \\
& 4400 \pm 100 \\
& 2450 \text { B.C. } \\
& 4580 \pm 200 \\
& 2630 \text { B.C. } \\
& 4900 \pm 120 \\
& 2950 \text { B.c. } \\
& 5820 \pm 120 \\
& 3870 \text { B.C. } \\
& 6170 \pm 120 \\
& 4220 \text { в.C. } \\
& 7400 \pm 120 \\
& 5450 \text { в.c. } \\
& 8030 \pm 120 \\
& 6080 \text { B.C. }
\end{aligned}
$$




\section{Auvernier series, Lac de Neuchâtel, Switzerland}

Charcoal and wood (piles and boards) from Neolithic settlement at Auvernier, Lake Neuchâtel (46 $56^{\circ} 16^{\prime \prime} \mathrm{N}$ Lat, 6 $6^{\circ} 52^{\prime} 24^{\prime \prime}$ E Long). From cultural layer, 0.8 to $1.0 \mathrm{~m}$ thick, ca. 0.1 to $0.15 \mathrm{~m}$ below present lake bottom, 10 to $50 \mathrm{~m}$ off modern shoreline. Coll. 1964 and 1965 by Ch. Strahm and J. P. Jéquier; subm. by Ch. Strahm, Univ. of Freiburg i.Br. Germany. Comment (Ch.St.): site is archaeologically dated by imports from the Schnurkeramik Civilization and belongs to the Swiss late Neolithic. Good archaeological proof exists for repeated use of site during longer time range. Oak trunk, sample B-690 (4630 \pm 100$)$, is evidently out of place in the settlement series. This is in agreement with stratigraphic position $10 \mathrm{~m}$ below oldest part of cultural layer in a distinctively older sediment.

\begin{tabular}{|c|c|c|}
\hline B-685. & Auvernier & $\begin{array}{l}4000 \pm 120 \\
2050 \text { в.C. }\end{array}$ \\
\hline B-686. & Auvernier & $\begin{array}{l}4160 \pm 100 \\
2210 \text { B.C. }\end{array}$ \\
\hline B-687. & Auvernier & $\begin{array}{l}3990 \pm 100 \\
2040 \text { в.C. }\end{array}$ \\
\hline B-688. & Auvernier & $\begin{array}{l}4140 \pm 140 \\
2190 \text { в.C. }\end{array}$ \\
\hline B-689. & Auvernier & $\begin{array}{l}4130 \pm 100 \\
2180 \text { B.C. }\end{array}$ \\
\hline B-690. & Auvernier & $\begin{array}{l}4630 \pm 100 \\
2680 \text { в.c. }\end{array}$ \\
\hline B-643. & Auvernier & $\begin{array}{l}4160 \pm 120 \\
2210 \text { B.c. }\end{array}$ \\
\hline B-644. & Auvernier & $\begin{array}{l}4000 \pm 150 \\
2050 \text { в.C. }\end{array}$ \\
\hline B-645. & Auvernier & $\begin{array}{l}4180 \pm 120 \\
2230 \text { B.C. }\end{array}$ \\
\hline B-646. & Auvernier & $\begin{array}{l}3960 \pm 120 \\
2012 \text { B.C. }\end{array}$ \\
\hline
\end{tabular}

\section{Wachseldorn series, Switzerland}

Turf of sedges and Hypnaceae, at base of peat works, at Wachseldorn, E of Thun and the Aaretal (46 49' $15^{\prime \prime} \mathrm{N}$ Lat, $7^{\circ} 44^{\prime} 5^{\prime \prime} \mathrm{E}$ Long) at alt $1000 \mathrm{~m}$ above sealevel in Tertiary (Molasse) landscape $\mathrm{N}$ of Alps, where present climate is harsh. Coll. 1965 by K. Heeb and M. Welten, Univ. of Bern. Comment (M.W.): this exceptionally important pollen diagram of late-glacial times has been analyzed by K. Heeb; it demonstrates presence of Bölling and Alleröd as well as Younger Dryas, cool- 
climate zones being dominated by grasspollen. The $\mathrm{C}^{14}$ series is clearly consistent with Heeb's interpretation.

B-700. Wachseldorn, $416 \mathrm{~cm}$ depth

$\mathbf{1 0 , 5 5 0} \pm \mathbf{1 5 0}$ 8600 B.C.

B-701. Wachseldorn, $421 \mathrm{~cm}$ depth

$10,320 \pm 150$ 8370 B.C.

B-702. Wachseldorn, $451 \mathrm{~cm}$ depth $10,980 \pm 200$ 9030 B.C.

B-703. Wechseldorn, $466 \mathrm{~cm}$ depth $11,660 \pm 150$ 9710 в.C.

B-704. Wachseldorn, $470 \mathrm{~cm}$ depth

$11,810 \pm 150$ 9860 B.C.

B-705. Wachseldorn, $479 \mathrm{~cm}$ depth $12,345 \pm 150$ 10,395 в.c.

B-706. Wachseldorn, $481 \mathrm{~cm}$ depth $12,210 \pm 150$ 10,260 B.c.

B-707. Wachseldorn, $489 \mathrm{~cm}$ depth $12,395 \pm 130$ 10,445 B.c.

B-708. Wachseldorn, $491 \mathrm{~cm}$ depth $12,500 \pm 150$ 10,550 в.c.

B-709. Wachseldorn, 505 cm depth $12,915 \pm 130$ 10,965 в.c.

Sur-Les-Bieds series, Vallée des Ponts, Switzerland

Material from wall of typical peat-bog of Haute Jura Neuchâtelois, close to Sur-les-Bieds (46 $58^{\prime} 52^{\prime \prime}$ N Lat, 6 ${ }^{\circ} 44^{\prime} 25^{\prime \prime}$ E Long). Coll. 1964 and subm. by Francois Matthey, Univ. of Neuchâtel. Comment: see Sous Martel-Dernier series (B-714 to B-716, this date list).

B-710. Sur-Les-Bieds, 290-260 cm depth $9360 \pm 100$ 7410 B.c.

Corylus and Quercetum mixtum phase; Pinus maximum.

B-711. Sur-Les-Bieds, $200 \mathrm{~cm}$ depth $6930 \pm 100$ 4980 B.c.

Development of Abies increase of Quercetum mixtum and decrease of Corylus.

B-712. Sur-Les-Bieds, $150 \mathrm{~cm}$ depth $5730 \pm 100$ Intensive spread of Abies and decrease of Quercetum mixtum.

B-713. Sur-Les-Bieds, $100 \mathrm{~cm}$ depth $4430 \pm 100$ 2480 B.c.

First important appearance of Picea in the Vallée des Ponts. 
Sous Martel-Dernier series, Vallée des Ponts, Switzerland

Material from wall of typical peat-bog of Haute Jura Neuchâtelois close to Sous Martel-Dernier (46 $58^{\prime} 51^{\prime \prime} \mathrm{N}$ Lat, $6^{\circ} 42^{\prime} 49^{\prime \prime} \mathrm{E}$ Long). Coll. 1964 and subm. by F. Matthey, Univ. of Neuchâtel. Comment (F.M.): the Sur-les-Bieds and Sous Martel-Dernier series date postglacial development of vegetation in Valléé des Ponts. Deposition during Alleröd phase is established.

$$
10,950 \pm 120
$$

B-714. Sous Martel-Dernier, 300-270 cm depth 9000 в.c.

Second maximum of Juniperus; after a first maximum Pinus shows a short decrease followed by a second extension.

B-715. Sous Martel-Dernier, $250 \mathrm{em}$ depth 6650 в.c.

Corylus and Quercetum-mixtum phase; strong decrease of Pinus.

\section{B-716. Sous Martel-Dernier, $150 \mathrm{~cm}$ depth 2290 B.c.}

Decrease of Corylus and Quercetum mixtum; increase of Abies.

\section{Le Grand Cachot series, Vallée de la Brévine, Switzerland}

Samples from wall of typical peat-bog of Haute Jura Neuchâtelois close to Le Grand Cachot (47 $0^{\prime} 24^{\prime \prime} \mathrm{N}$ Lat, $6^{\circ} 40^{\prime} 41^{\prime \prime}$ E Long). Coll. 1964 and subm. by F. Matthey. Comment (F.M.): B-717 dates beginning of colonization of Vallée de la Brévine by Abies; B-718 marks crossing of curves for increasing Abies and decreasing Quercetum-mixtum pollen.

\section{B-717. Le Grand Cachot, $290 \mathrm{~cm}$ depth}

$6220 \pm 100$

Extension of Abies.

\section{B-718. Le Grand Cachot, $250 \mathrm{~cm}$ depth}

$4830 \pm 100$

First maximum of Abies and appearance of Picea.

\section{B.917. Noiraigue: "Les Marais," Switzerland}

$5820 \pm 100$

3870 B.c.

Peat from lowest layer of bog on chalky sediment of ancient lake in Val de Travers (46 $57^{\prime} 15^{\prime \prime} \mathrm{N}$ Lat, $6^{\circ} 42^{\prime} 56^{\prime \prime}$ E Long). Coll. 1965 and subm. by F. Matthey. Comment (F.M.): sample dates disappearance of lake from Val de Travers.

\section{B.720. Les Saignolis, Switzerland}

Peat from bog on marl of "Chaîne de Poillerel" $\left(47^{\circ} 5^{\prime} 17^{\prime}\right.$ " N Lat, $6^{\circ} 45^{\prime} 56^{\prime \prime}$ E Long). Coll. 1965 and subm. by F. Matthey. Comment (F.M.): peat of sphagnum lies directly on mineral (calcareous) ground, forming a very special type of bog; strong leaching prior to peat formation is implied. 
B-725. Salchendorf, Germany

$480 \pm 100$

Charcoal, found during construction of a woodland path at Salchendorf $\left(50^{\circ} 48^{\prime} 30^{\prime \prime} \mathrm{N}\right.$ Lat, $7^{\circ} 59^{\prime} 50^{\prime \prime} \mathrm{E}$ Long). Coll. 1965 by Alfred Henrichs; subm. by W. Kolb, Physikalisch-technische Bundesanstalt, Braunschweig.

\section{B-730. Aesch, Klushof, Switzerland}

$1565 \pm 90$

Wood (Vitis vinifera) found during excavation at depth of $4 \mathrm{~m}$ in culture layer at Klushof, Aesch $\left(47^{\circ} 28^{\prime} \mathrm{N}\right.$ Lat, $7^{\circ} 36^{\prime} \mathrm{E}$ Long). Coll. 1965 and subm. by Sandoz AG., Basel. Comment (S.): result supports presumption that vine was grown during Roman occupation $\mathrm{N}$ of Alps.

\section{Burgmoos series, Seeberg, Canton Bern, Switzerland}

Dark humus layer, found by boring at edge of ancient late-glacial

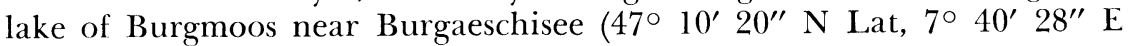
Long, alt $465 \mathrm{~m})$. Coll. 1965 by Welten and V. Markgraf; subm. by M. Welten. Comment (M.W.): palynological results did not agree with the supposed Alleröd age, inferred from position under less organic sediment. Material proved to be Anmoos (i.e., a humus-rich soil). Cit dating assigned layer to Younger Dryas, proving an unusual stratigraphy of late-glacial lake-border sediments.

\section{B-731. Burgmoos I, $235 \mathrm{~cm}$ depth}

$$
\begin{gathered}
10,460 \pm 140 \\
8510 \text { в.C. } \\
10,490 \pm 170 \\
8540 \text { в.C. }
\end{gathered}
$$

\section{B-732. Burgmoos I, 242 cm depth}

\section{B-736. Zentral-EIburz, Iran}

$>38,500$

Clayey and silty material mixed with plant remains from filling of a Young Pleistocene lake in the Lar-Tal $\left(35^{\circ} 53^{\prime} 30^{\prime \prime} \mathrm{N}\right.$ Lat, $51^{\circ} 59^{\prime} 30^{\prime \prime}$ E Long), SW of volcano Damavand, Iran. Coll. 1962 and subm. by P. Allenbach, Federal Inst. of Tech. Comment (P.A.): date is minimum age for the southernmost lava deposits of volcano Damavand which dammed the Pleïstocene lake (Allenbach, 1966).

\section{B-754. Tabo Temple, Sudan}

$$
1870 \pm 80
$$

A.D. 80

Wood from temple Tabo, Ile d'Argo, Sudan $\left(19^{\circ} 23^{\prime} \mathrm{N}\right.$ Lat, $30^{\circ} 28^{\prime}$ E Long) found on floor covered with stone slabs close to central portal. Coll. 1966 and subm. by Charles Bonnet, Univ. of Genève. Comment (Ch.B.): date confirms that temple was constructed or reconstructed during the Meroitic epoch.

\section{B.C.}

Upper $1 \mathrm{~cm}$ of a dy-gyttja layer, $5 \mathrm{~cm}$ thick, at $555 \mathrm{~cm}$ depth below surface, representing beginning of Pinus period from Boltigen, Chutti, 
Simmental, Bernese Oberland (46 $38^{\prime} 10^{\prime \prime} \mathrm{N}$ Lat, $7^{\circ} 23^{\prime} 42^{\prime \prime}$ E Long). Coll. 1966 and subm. by M. Welten, Comment (M.W.): result supports B-75 (11,230 \pm 380 , Bern I), obtained for a sample covering the whole 5 -cm-thick layer. $7.5 \mathrm{~cm}$ above sample is thin layer of volcanic ash, age of which estimated ca. 8800 B.c.

\section{Boltigen, Chutti series, Simmental, Switzerland}

Peat of Hypnaceae from Boltigen, Chutti, Simmental, Bernese Oberland $\left(46^{\circ} 38^{\prime} 10^{\prime \prime} \mathrm{N}\right.$ Lat, $7^{\circ} 23^{\prime} 42^{\prime \prime}$ E Long, alt $\left.925 \mathrm{~m}\right)$. Coll. and subm. 1966 by M. Welten. Comment (M.W.): samples represent beginning of development of peat above reddish and gray chalk with increased Artemisia content. For beginning of deposition of traces of pollen of xerophytic trees an approximate age of 8200 B.c. is obtained by extrapolation. This is in good agreement with other results.

\section{B-773. Boltigen, Chutti, $508.5 \mathrm{~cm}$}

\section{B-774. Boltigen, Chutti, $500 \mathrm{~cm}$ depth}

\section{REFERENCFS}

Date lists:

$$
\begin{array}{ll}
\text { Bern I } & \text { Oeschger, Schwarz and Gfeller, } 1959 \\
\text { Bern IV } & \text { Oeschger and Riesen, 1965 }
\end{array}
$$

Allenbach, P., 1966, Geologie und Petrographie des Damavand und seiner Umgebung (Zentral-Elburz), Iran: Mitteilungen aus dem Geologischen Institut der ETH und der Univ. Zürich.

Langway, C. C., Jun., Oeschger, H., Renaud, A., Alder, B., 1965, Sampling polar ice for radiocarbon dating: Nature, v. 206, p. 500.

Loosli, H. H., 1963, Zählrohr für $\mathrm{C}^{14}$-Altersbestimmungen an kleinen Proben: Physikalisches Inst. der Univ. Bern, thesis.

Oeschger, H., Schwarz, U., Gfeller, Chr. 1959, Bern radiocarbon dates I: Am. Jour. Sci. Radioc. Supp., v. 1, p. 133-143.

Oeschger, H., 1963, Low-level counting methods: Radioactive Dating, IAEA, Vienna, p. 13-34.

Oeschger, H., Riesen, T., 1965, Bern radiocarbon dates IV: Radiocarbon, v. 7, p. 1-9.

Oeschger, H., Alder, B., Loosli, H. H., Langway, C. C., Jun., Renaud, A., 1966, Radiocarbon dating of ice: Earth and Planetary Science Letters, v. 1, p. 49-54. 